\title{
7. Making Policy and Winning Votes: Election promises and political strategies in the 2013 campaign
}

\author{
Nicholas Reece
}

This chapter examines the intersection of public policy and politics in the 2013 federal election campaign. More than any other point in the political cycle, election campaigns are a time in which candidates and political parties release a large amount of new policy in the hope that it will win them increased public support. The candidates and the parties also attack the policies and policy record of their opponents to decrease support for their competitors. Political parties release policy they claim will benefit the nation. But, the parties also use policies in a highly strategic way to enhance their campaign and outmanoeuvre their opponents.

Election studies have shown the growing importance of election policies and issues in deciding the outcome of elections (Dalton 2000; McAllister 2011). Long-term factors such as social background and socio-economic status do not have the same level of influence on a person's voting behaviour as they once did (McAllister 2011). The electorate has also become more fragmented, without the relatively homogeneous personal networks and social structures of previous eras. These factors have helped cause a decline in partisanship. As a consequence the political environment is now one in which voting patterns are far more volatile. Shorter-term influences on the vote, such as parties' policy positions and preferences, performance evaluation and leaders' public profiles, have emerged to fill the gap left by the decline of longer-term influences (Dalton 2000).

The 2013 Australian federal election illustrates how political parties have adapted to the greater importance of policy and issue voting and to broader changes in the electorate. At least symbolically, this was demonstrated by the Liberal Party which produced five million copies of its policy manifesto and distributed it to households across Australia. It has been several decades since a policy document - albeit a glossy 16-page summary version - has been produced and distributed on this scale.

This chapter will show that the major political parties have become more sophisticated in their development and strategic use of policy. Methods include the engagement of market research teams to assist with the positioning and public presentation of policies. The parties have become highly tactical in 
their use of policy to achieve political objectives such as the wedging of an opposition party, targeting specific voter groups or keeping the media focus on a desired policy area. Many policies announced during the 2013 election were the product of a lengthy development process, while other policies were 'made up on the run' to meet a pressing political objective. For different reasons, there were a significant number of policies that were drafted by Labor and the Liberals but never released publicly. The major parties have also adopted the practice of 'gaming' the policy costing process that was established under the Charter of Budget Honesty in 1998 such that the process is no longer meeting its objectives.

The chapter first provides an overview of the policy development process used by the Liberal and Labor parties in the 2013 campaign, including the formal approval process and the adoption of ad hoc, spur-of-the-moment announcements and the attendant controversies over policy costings. It then identifies the salient issues of the campaign as identified by voters through surveys such as Vote Compass, and catalogues the major policies announced by the parties in the election. Thirdly, it examines the ways in which the parties used policies to achieve political strategic objectives during the campaign.

This chapter is based on interviews with senior campaign figures in the Labor and Liberal parties as well as the author's personal experience as a campaign director and coordinator of the policy development process for a major political party in previous Australian elections. The study is confined to the ALP and Coalition (Liberal and National) parties and does not examine the policies and strategies of the Greens and other minor parties.

\section{The policy development process behind the 2013 campaigns}

Both the Liberal and Labor parties have a highly developed process for drafting and approving election policies. Notwithstanding party rules requiring varying degrees of consultation with party members, the policy development process has become highly centralised. This reflects the pressure of media and campaign management and the specialised nature of policy making in certain fields. The parties have become highly reliant on market research and data analytics to identify groups of party supporters and persuadable voters (Penn 2007; Hawker 2013). Using this information, a plan is developed to try and build a winning coalition of supporters. 


\section{Policy development in the Coalition parties}

Senior shadow minister Andrew Robb led the policy development process for the Liberal Party as the chairman of the Coalition Policy Development Committee. This was essentially a three-year process that commenced with a review of the Coalition's policies after the 2010 election. Robb is a former federal director of the Liberal Party and was a federal campaign manager for the 1993 and 1996 campaigns. Joe Hockey and Andrew Robb also oversaw a costings process for the Opposition. This involved a process of internal scrutiny, consultation with stakeholders, assessment by the Parliamentary Budget Office (PBO) and a panel of review by three 'eminent experts in public finance and administration' comprising former top bureaucrat Peter Shergold, economist Geoff Carmody and former Queensland auditor-general Len Scanlan.

Liberal Federal Director, Brian Loughnane, and market research and political strategy firm Crosby Textor, led by Mark Textor, provided input on framing the election contest, the overarching narrative for the campaign, testing of TV ads and marketing materials, demographic analysis of target voter groups and a list of target seats for the Liberal campaign. Crosby Textor also provided market research feedback on various ALP policy positions and the policy positions and options for the Coalition. Textor had been Liberal Party campaign pollster for six federal campaigns from 1996 to 2010.

The Coalition's strategy was not simply to run a negative commentary on six years of Labor Government, but also to demonstrate that it was 'time for real change' (Textor 2013). Key policies such as abolishing the carbon tax, introducing the paid parental leave (PPL) scheme and direct action on the environment were symbols of change. The Liberals' policy program was presented as 'carefully managed change' not as a radical new agenda. This fitted with the broader strategy to present the Coalition as a 'safe' alternative to the incumbent Labor Government. The Coalition claimed it would be a government that was 'grown up' and run by 'adults' and committed to being 'a government of no surprises' that would 'under-promise and over-deliver'.

One of the distinctive features of the 2010 election was the way in which state results swung in different directions. In 2013, the Liberals hoped to win additional seats in Victoria, South Australia, Tasmania and New South Wales. These states had held out against the national swing against Labor in 2010. The Liberals also wanted to reverse the female voting imbalance that had worked against the Party in 2010. Both major parties continued to target young families. Typically, this implies a household with children in school, where Dad has a trade qualification or works in an administrative white-collar role and Mum 
works part-time. This young family has an above average level of mortgage stress, faces cost of living pressures and uses a car as the principal mode of transport.

\section{Policy development in the Australian Labor Party}

The ALP election policy development process ran for approximately nine months leading up to the September election. Senior minister in the Gillard and Rudd governments, Jenny Macklin, chaired an Election Expenditure Review Committee. Following the leadership change from Gillard to Rudd in June 2013 there were significant ministerial and staff changes and much of this process fell into abeyance. National Secretary of the ALP, George Wright, revealed that of the 150 staff slated to work in the Party's national campaign headquarters, 110 resigned following the change of leadership (Wright 2013).

As a consequence of these changes many of the policies that were released by Labor during the campaign did not go through a rigorous governance arrangement. Some of the most high profile included the establishment of a special economic zone in the north of Australia; the policy to move the Australian Navy from Sydney's Garden Island facility to Brisbane; and Rudd's call for a tightening of foreign investment rules in the guise of 'economic nationalism' (Hawker 2013).

Rudd relied on a number of key campaign advisors. The ALP's National Secretary George Wright, the campaign firm Essential Media Communications (EMC), John Utting from polling firm UMR, and Tony Mitchelmore, provided research input on framing the election contest, the overarching narrative for the campaign, demographic analysis of target voter groups and a list of target seats. Late in the campaign preparation process, advertising executive Neil Lawrence was commissioned to prepare the ALP launch advertisement and the campaign slogan 'A New Way'. This was not done in consultation with the ALP's national secretariat nor with EMC who produced other advertisements and messaging for the campaign such as the 'If he wins you lose' attack advertisements against Tony Abbott.

Labor's market research told it that ALP in-fighting and lack of discipline had made the Party unworthy of re-election in many voters' eyes. On the policy front, the steady increase in asylum seeker arrivals by boat was costing the ALP support amongst key target voter groups. Slower growth in the economy and deficit budgets had made people uncertain about the economic future. For the ALP, the target voter groups in 2013 were those who had deserted Labor since the 2010 election, followed by those they had lost at the 2010 election itself. Some of the key demographics of these groups included men with trade 
qualifications, Queenslanders, Western Australians and Tasmanians. Like the Coalition, Labor was also chasing the young families that comprise a large portion of the marginal electorates in outer suburban and regional Australia.

\section{The election policy costing process}

The establishment of the statutory Charter of Budget Honesty in 1998 and the Parliamentary Budget Office (PBO) in 2012 were intended to bring a new level of transparency and honesty to the costing of election promises. Despite these reforms, the process for costing and disclosing the budget impact of policies descended into high farce in the 2013 Australian election as the major parties discovered how to game the system.

The Coalition took advantage of the new resources available to it through the PBO and submitted more than 200 policy commitments for costing. However, the Coalition did not submit a single policy to Treasury and the Department of Finance and Regulation for costing during the caretaker period. As outlined earlier, the Coalition instead used its own panel of review comprising three 'eminent experts in public finance and administration'. The Coalition released over 700 pages of policy documents for the 2013 campaign but only released the associated policy cost and budget impact two days before the election. These did not include an independent costing for three of its biggest financial commitments: the NBN, its Direct Action Plan on climate change, and its asylum seeker and border security measures.

Labor submitted its policy commitments through the Treasury and Finance process and released them progressively throughout the campaign. Labor tried to make a virtue of doing this while attacking the Coalition for not participating. However, Labor got into trouble when it submitted a series of initiatives for costing that it had no intention of pursuing itself but thought the Coalition might. This was not part of a policy development process but an election tactic to expose the Opposition for an alleged 'budget black hole'. But the tactic backfired when Treasury and Finance issued statements saying Labor had misrepresented their findings.

\section{Issues and policies of the 2013 campaign}

From one election to another the issues that are of highest priority to voters change. The political parties monitor changes in issue salience and shape their policy offerings and marketing campaigns accordingly. Set out in Table 1 is an issue salience list from the 2013 election. 


\section{The issues in 2013}

In 2013, the University of Melbourne, University of Sydney and the ABC in cooperation with political scientists at the University of Toronto developed Vote Compass for the Australian election. Vote Compass was an online educational tool to help voters understand where they stand on the issues compared to the parties. The survey was completed voluntarily 1.4 million times. This sample was then adjusted using the ABS census and other data sets to produce an estimate of voter attitudes (Vote Compass 2013a).

\section{Table 1: Issue salience in the 2013 election}

\begin{tabular}{|l|l|}
\hline Issue & Per cent mention \\
\hline Economy & 28 \\
\hline Asylum seekers & 13 \\
\hline Health and hospitals & 10 \\
\hline Climate change & 9 \\
\hline Education & 9 \\
\hline Broadband & 7 \\
\hline Taxation & 3 \\
\hline
\end{tabular}

Source: Vote Compass. Respondents were asked: 'Which issue is most important to you personally in this election campaign?'

As a useful point of comparison the Australian Electoral Study produced the following results on issue salience amongst a sample of voters in the 2010 election.

Table 2: Issue salience in the 2010 election $^{1}$

\begin{tabular}{|l|l|}
\hline Issue & Per cent mention \\
\hline Health and Medicare & 23 \\
\hline Management of the economy & 21 \\
\hline Education & 13 \\
\hline Global warming & 8 \\
\hline Interest rates & 7 \\
\hline Taxation & 7 \\
\hline Refugees and asylum seekers & 6 \\
\hline
\end{tabular}

Source: Australian Electoral Study 2010. Respondents were asked: 'Still thinking of these 12 issues, which of these issues has been most important to you and your family during the election campaign?'

A comparison of the 2013 and 2010 results shows some significant changes amongst the issue priorities of voters. The economy was a significantly more

1 At the time of publication the results for the AES 2013 had not been released. 
important issue to voters in 2013 compared to 2010 as well as being far more important relative to other issues in 2013. Asylum seeker and refugee policy was the second most important issue in 2013 while it was only seventh in 2010. Health and education issues both slipped in importance compared to 2010 .

The issues on which an election is fought are a key consideration for the parties in formulating their campaign strategy. This is because different parties are seen as being best able to handle certain issues. In general, debates about health and education will deliver more benefits to centre-left parties like the Labor Party. Debates about border security, taxation and to a lesser extent the economy benefit centre-right parties like the Coalition (McAllister 2011). This is part of the 'brand essence' of these parties. The changes in the issue landscape between 2010 and 2013 benefited the Coalition at the expense of Labor as the issues which the Coalition was seen as being best able to handle had greater salience for voters than in 2010 .

\section{The major policies announced in 2013}

Set out below are the major policy announcements made by the major parties during the campaign. This list has been determined using a mixed methodology that takes into account the following factors: a review of all the policy documents released; the campaign launch speech by the party leaders; media mentions of specific policies; the level of expenditure committed to a policy initiative; and policies which featured in party advertising.

The major policies announced by Tony Abbott and the Coalition

- Scrap the carbon tax and abolish the Clean Energy Finance Corporation;

- 'Stop the boats' through 'Operation Sovereign Borders', including boat buybacks and towing back the boats;

- Abolish the mining tax;

- $\$ 17$ billion in budget savings including a reduction of 12,000 public servants;

- Build the roads of the 21st century: the WestConnex in Sydney, the East West Link in Melbourne, the Gateway Upgrade in Brisbane, the North South Road in Adelaide and the Swan Bypass in Perth;

- Cut the company tax rate by 1.5 per cent;

- Cut red tape by $\$ 1$ billion a year;

- Move the workplace relations pendulum 'back to the sensible centre': restore the Australian Building and Construction Commission (ABCC), introduce new penalties for 'dodgy' union officials;

- Reinstate the fringe benefits tax exemption on company cars that are salary packaged at a cost of $\$ 1.8$ billion; 
- Build a National Broadband Network (NBN) that is slower but cheaper;

- Introduce a standing Green Army, growing to some 15,000 individuals;

- Deliver on the National Disability Insurance Scheme (NDIS);

- Abolish the School Kids Bonus;

- Abolish the low-income super offset funded by the mining tax;

- Delay the Superannuation Guarantee Levy increase;

- Stop the scheduled increase in the humanitarian migrant intake;

- Support the 'Gonski funding reforms' for three years;

- A Paid Parental Leave (PPL) scheme, paid to working women at their actual wage up to $\$ 150,000$;

- Index eligibility thresholds for the Commonwealth Seniors Health Card;

- Commit an additional \$200 million to dementia research;

- Give apprentices access to a $\$ 20,000$ loan, similar to that enjoyed by university students;

- A more functional Federation where the states are sovereign in their own sphere;

- Public schools and hospitals will have local boards and more autonomy;

- By the end of the first term, the budget will be on track to a believable surplus;

- Within a decade, the budget surplus will be one per cent of GDP, defence spending will be two per cent of GDP, and each year government will compromise a progressively smaller percentage of the national economy;

- Restore the Private Health Insurance Rebate within a decade; and,

- Recognise indigenous people in the Constitution, and Tony Abbott as prime minister will spend a week a year in a remote indigenous community.

The major policies announced by Kevin Rudd and the ALP

- Abolish the carbon tax by bringing forward an Emissions Trading Scheme (ETS) by one year;

- The 'PNG solution' to provide offshore processing and settlement for irregular maritime arrivals in Papua New Guinea;

- Reform of the ALP, including direct election of the Party leader;

- Introduce legislation in the first 100 days to support same-sex marriage;

- Build an NBN using the best broadband technologies;

- The Northern Australia Plan including a special tax zone in Australia's north;

- Maintain Australia's low debt and deficit levels;

- The Small Business Tax Boost: an upfront tax deduction on the purchase of new equipment; 
- All projects worth $\$ 300$ million or more to adopt Australian Industry Participation Plans;

- Increase the 'Tools for Your Trade' payment to apprentices to $\$ 6,000$;

- Require state governments to maintain and grow their funding of TAFE; failing this, a Commonwealth takeover of the TAFE sector;

- A new Jobs, Training and Apprenticeships Guarantee (JTAG) and a new institution called Jobs and Training Australia to bring together the employment services and training systems;

- Implement the Better Schools Plan with \$15 billion of additional investment;

- Build the health and hospital system for the future with an additional \$19 billion investment;

- Build a Clean Energy Future and keep the Clean Energy Finance Corporation;

- Maintain the School Kids Bonus;

- Keep the FairWork Australia industrial relations system to protect penalty rates and overtime;

- Keep the current Paid Paternity Leave scheme based on the minimum wage;

- Relocate the naval base at Garden Island in Sydney to northern Australia;

- Reject any review of the GST; and,

- Reject the alleged $\$ 70$ billion in cuts to be made by the Opposition.

\section{Those policies the public never got to see}

One of the great unknowns and imponderables of the 2013 federal election is the slate of policies that the public never got to see. Interviews for this chapter have confirmed that much of the policy work that was done by ministers and senior advisers in the Gillard Government in the months leading up to the June leadership change were not adopted by new prime minister Kevin Rudd. Meanwhile, the Coalition did not release many of the policies it had drafted because it had a commanding lead in the polls and opted for a small target strategy. This involved holding back policy so as to avoid attack from their opponents on policy detail. The tight fiscal environment also significantly curtailed the more ambitious policy ideas of both major parties.

\section{The tactical use of policy to deliver campaign strategy}

Most election policies announced by political parties involve a calculated combination of good policy and good politics. This section focuses on the political objectives of policies developed for the campaign rather than their 
policy objectives. This process may be thought of as something like a chess game in which each side moves its pieces - in this case, policies - to achieve a strategic campaign objective. While there is scholarly consensus about the increased importance of policy and issue voting in modern election campaigns, much less is understood about the way political parties use policies in a tactical way to achieve their broader campaign strategy. The following section helps fill this knowledge gap by outlining how election policies were used by the major parties during the 2013 election to deliver on political campaign objectives.

\section{Demonstrate a vision for the future}

One of the key ingredients for electoral success is to demonstrate a vision for the future. This is usually done by outlining a narrative of what the future looks like, supported by the policies that 'build the bridge' toward it. One of the more interesting ways the Coalition did this was through the publication of its 52-page Real Solutions Plan in early 2013. Over five million copies of a 16-page condensed version were circulated to households across Australia. Coalition strategists knew that the document would not be widely read. But they believed that its presence in millions of households sent a strong message about the Coalition having a plan for the future and being ready for government. The print distribution was also supplemented by electronic advertising promoting the Plan from early 2013 through to mid-2013 (Loughnane 2013). For the Coalition, the plan to 'build the roads of the 21 st century' was also a key policy to help achieve this objective.

One of the shortcomings of Labor's campaign was its failure to build an agenda for the future. Labor's policies to tackle climate change and build the NBN had been central to its 'future vision' since 2007. However, by the 2013 campaign these policies had become tarnished by implementation challenges and political debate. The Northern Australia Plan was part of a future vision but attracted significant media scepticism, especially as Labor had earlier severely criticised a similar set of proposals emanating from the Coalition. The campaign launch contained some very significant new initiatives on training and apprenticeships but these came too late to have a major impact.

\section{Policy as values and policy to characterise the leader}

For well over a decade, conservative and progressive American academics and campaign consultants have been highlighting the importance of 'values' in framing political issues (Lakoff 2004; 2006; Luntz 2007). Accordingly, policy is marketed to the public not just in terms of its underlying benefit to society but also as a way of communicating the values and character of the party and its leader. 
Tony Abbott's promise to spend one week a year as prime minister in a remote indigenous community was used to promote his commitment to addressing Indigenous issues and his personal empathy for those facing disadvantage. The Coalition also worked to keep the carbon tax policy debate on the agenda during the election campaign. This debate in fact helped the Coalition in other debates about economics and cost of living, both of which were critical issues amongst target voters. The carbon tax debate also fuelled a values debate about broken promises and trust. This is because Julia Gillard and Labor were viewed by many as having broken a promise not to introduce a carbon tax.

For Labor, Kevin Rudd's reforms to the ALP helped meet the political objective of improving the tarnished brand of the Party. It also demonstrated Rudd's strength as leader and allowed him to talk about his values, including 'sticking up for the little guy' and giving ordinary people a say.

\section{Policy to win support from targeted constituencies}

Democratically elected politicians have always searched for policies that they believe will win over certain constituencies. However, recent advances in data analysis have allowed many of these policy decisions to be data-driven and to reflect micro-targeting approaches. The Coalition's policy to suspend fishing restrictions around marine national parks was a direct play to fishing groups and Australia's five million recreational fishers. The Coalition also released an Economic Growth Plan for Tasmania. Tasmania was the only state to be the beneficiary of such a plan. It is also the state where the Coalition did not win a single House of Representative seat in 2010 and stood to make significant electoral gains in 2013. The Coalition's very generous PPL scheme attracted criticism from Labor and others. However, the Coalition was happy to have this debate as the PPL was a key policy offer to working mums, a key voter group with which the Coalition had underperformed in 2010.

Labor's policy on gay marriage helped portray Rudd as a modern leader and to mobilise the Party's activist base which is critical for its campaign volunteer efforts. Kevin Rudd's policy of bringing forward a floating carbon price by one year and portraying this as 'axing the tax' was aimed squarely at ALP voters who had abandoned the Party since the last election. Both parties offered significant inducements to trade apprentices, well-known as an important target voter group in elections. The Coalition offered apprentices a $\$ 20,000$ HECS-type loan while Labor offered a $\$ 6,000$ grant for tools. 


\section{Policy to move the election debate onto preferred territory}

As previously outlined, defining the issue territory on which an election is fought is a key campaign strategy for the parties and each party attempts to move the debate onto issues where it is seen to have an advantage over its competitors. For the Coalition, the incremental announcement of border security policiessuch as Operation Sovereign Borders, the boats buy-back scheme and the 'tow back of boats' - was part of a strategy to keep the debate in an area it is seen as being best able to manage. For Labor the centrepiece policy of its campaign launch was a series of major announcements on TAFE education and training, including the possible takeover of the TAFE sector by the Commonwealth. This was an attempt to move the policy debate to an issue that voters believe the ALP handles best.

\section{Policy to keep the election debate off the opponent's territory}

Just as parties use policy to move the public debate to their issues they also use it to stop debate in a policy area that is their opponent's strong point. The 2013 election provides several examples of this tactic. Labor's policy to support off-shore processing and the settlement of asylum seekers in PNG was aimed at shutting down debate on an issue that was seen as a Coalition strength. The Coalition's decision to adopt Labor's Better Schools funding agreement with the states, support DisabilityCare, amend its NBN plans to be more like Labor's and to declare WorkChoices dead were all aimed at shutting down political debate on issues that were viewed as Labor strengths.

\section{Policy to 'wedge' the opponent}

A wedge issue is one that is divisive or controversial and can split a population or political group. Political campaigns use a wedge policy to exploit tension within a targeted population. The objective is to divide the Opposition, create the impression of disunity, and drive the defection of supporters who are in the minority on that issue.

The debate on asylum seeker policy is a wedge issue par excellence for the ALP. A Vote Compass survey of 375,000 voters undertaken during the election campaign revealed that 48 per cent of Labor supporters disagreed with the Party's policy that asylum seekers who arrive by boat should not be allowed to settle in Australia, while 40 per cent of Labor voters agreed with the policy. In contrast, Coalition and Green voters were much more firmly locked in behind their parties' policy positions (Vote Compass 2013b). 
For the Coalition, an example of a wedge issue was the mining tax with the Liberal Party proposing to abolish the tax. A Vote Compass survey during the campaign showed that only 19 per cent of Liberal voters wanted the miners to pay less tax while 38 per cent wanted them to pay more and 43 per cent wanted them to pay the same (Vote Compass 2013c). Interestingly, the ALP did not pursue this policy during the election campaign. This was in part due to concerns about implementation problems with the tax and the risk of losing support in Western Australia and regional Queensland.

\section{Conclusion}

The 2013 election highlights the very strategic way in which political parties use policies to enhance their campaign and outmanoeuvre their opponents. The major political parties have become more sophisticated in the development and marketing of their policies. This includes the engagement of market research teams to assist with the positioning and public presentation of policies. The major parties have worked out how to game the policy costing process established under the Charter of Budget Honesty in 1998 and supplemented by the establishment of the PBO in 2012. This occurs to such an extent that the system now falls well short of meeting its stated legislative objectives. Even with the increased complexity of the policy development process, the 2013 election still included the release of policies that were 'made up on the run' to meet a pressing political objective. For different reasons, there were also a significant number of policies drafted by the major parties that were never released publicly.

Changes in issue salience between 2010 and 2013 worked to the Coalition's advantage. The Coalition was seen as being best able to handle issues that had risen in importance, such as the economy and asylum seekers. Meanwhile issues that were seen as a traditional strength of Labor, such as health and education, decreased in importance. Both the Liberal and Labor parties released a significant volume of policy during the 2013 campaign, with the key policies listed in this chapter. Both parties attempted to use policy in a tactical way to achieve certain campaign objectives.

\section{References}

Dalton, James. 2000. 'Citizen Attitudes and Political Behaviour'. Comparative Political Studies 33(6/7): 912-40.

Green, Donald P and Gerber, Alan S. 2003. 'Under provision of Experiments in Political Science'. Annals of the American Academy of Political and Social Science 589: 93-112. 
Hawker, Bruce. 2013. The Rudd Rebellion: The Campaign to Save Labor. Melbourne: Melbourne University Publishing.

Issenberg, Sasha. 2012. The Victory Lab. New York: Crown.

Lakoff, George. 2004. Don't Think of an Elephant. Hartford: Chelsea Green Publishing.

Loughnane, Brian. 2013. 'Address to the National Press Club'. Canberra, 23 October, viewed 26 October 2013: <lpaweb-static.s3.amazonaws. com/Brian \% 20Loughnane \% 20-\% 20National \% 20Press \% 20Club \% 20 Address \%20-\%2023\%200ctober \%202013.pdf>.

Luntz, Frank. 2007. Words that Work. New York: Hyperion.

McAllister, Ian. 2011. The Australian Voter: 50 years of change. Sydney: UNSW.

McAllister, Ian, Bean, Clive, Gibson, Rachel Kay and Pietsch, Juliet. 2011. Australian Election Study, 2010. Canberra: Australian Data Archive, ANU.

O'Malley, Nick and Johnson, Chris. 2013. 'How Barack Obama is changing the face of Australian political campaigns'. The Sydney Morning Herald, 4 August.

Penn, Mark. 2007. Microtrends: The small forces behind tomorrow's big changes. New York: Twelve.

Plouffe, David. 2009. The Audacity to Win. New York: Viking.

Textor, Mark. 2013. 'Why Tony Abbott won Australia's trust'. Australian Financial Review, 23 September.

Vote Compass. 2013a. 'Vote Compass Methodology'. Viewed 15 January 2014: <australia.votecompass.com/assets/media/site/pdfs/ VoteCompassMethodology.pdf $>$.

Vote Compass. 2013b. 'Kevin Rudd's Asylum Seeker Policy Divides the Labor Faithful'. ABC News, 21 August, viewed 15 January 2014: <www. abc.net.au/news/2013-08-21/asylum-seekers-vote-compass-boatsimmigration/4899914>.

Vote Compass. 2013c. 'The Most Important Issues to Voters'. ABC News, 9 August, viewed 15 January 2014: <www.abc.net.au/news/2013-08-09/votecompass-data-results-important-issues/4872896>.

Wright, George. 2013. 'Address to the National Press Club'. Canberra, 29 October, viewed 15 January 2014: <d3n8a8pro7vhmx.cloudfront.net/ australianlaborparty/pages/1890/attachments/original/1383017072/George_ Wright_Address_to_NPC_Transcript.pdf $>$. 
This text taken from Abbott's Gambit: The 2013 Australian Federal Election, edited by Carol Johnson and John Wanna, published 2015 by ANU Press, The Australian National University, Canberra, Australia. 